\title{
A REGIÃO DE FRONTEIRA SÃO BORJA-BRASIL/SANTO TOMÉ-ARGENTINA: AS REPRESENTAÇÕES SOCIAIS TRADICIONAIS PÓS CONSTRUÇÃO DA PONTE DA INTEGRAÇÃO (1994-1997)
}

\section{THE BORDER REGION OF SÃO BORJA-BRAZIL / SANTO TOMÉ- ARGENTINA TRADITIONAL SOCIAL REPRESENTATIONS AFTER CONSTRUCTION OF THE BRIDGE INTEGRATION (1994-1997)}

\author{
Muriel Pinto \\ Universidade Federal do Pampa/Campus de São Borja - São Borja - RS - Brasil \\ Ronaldo Bernardino Colvero \\ Universidade Federal do Pampa/Campus de São Borja - São Borja - RS - Brasil
}

\begin{abstract}
Resumo: A área de fronteira São Borja-Brasil/Santo Tomé-Argentina possui, desde o período reducional (século $\mathrm{XVI}$ ), uma relação marcada por processos de câmbios culturais, sociais, e econômicos. Essa fronteira possui como limite o rio Uruguai, corpo d'água que foi de grande importância para as comunicações culturais, comércio da erva-mate, acesso na Guerra do Paraguai, e para as práticas ribeirinhas na atualidade. No ano de 1997, foi construída, na fronteira, a ponte da Integração. Até então, o translado era via balsa. A trajetória histórica regional permitiu que fossem constituídas diversas práticas sociais, elementos culturais e identidades fronteiriças. O estudo proposto centrou-se em analisar as relações socioculturais da fronteira, voltando-se para a interpretação das articulações políticas durante o período de construção da ponte da Integração, das representações sociais e das identidades socioterritoriais. Para tanto, realizou-se análise de conteúdo jornalístico, da historiografia regional e das práticas socioculturais da porção brasileira da região fronteiriça em estudo. $O$ artigo instiga pensar a fronteira como uma região porosa e seletiva, que se caracteriza por uma identidade fronteiriça marcada por câmbios culturais missioneiros, gaúchos e ribeirinhos.
\end{abstract}

Palavras-chave: Ponte da integração. Fronteira Brasil-Argentina. Fronteira cultural. Representações sociais. Identidades fronteiriças. 


\begin{abstract}
The border area São Borja-Brazil / Santo Tomé-Argentina has since period reductional (century $\mathrm{XVI}$ ), a relationship marked by processes of cultural exchange, social, and economic. The proper border has as limit the river Uruguay, body of water that was of great importance to the trade of yerba mate, access the Paraguayan War, and pratices riverine present. In 1997, it was built on the border bridge Integration, until then the transfer was via balkan. The trajectory historical regional allowed to be incorporated diverse social practices, identities and cultural elements border. The proposed study focused on examining the relations socio-cultural of the border, turning to the interpretation of political during the construction of the bridge integration, social representations, and socio-territorial identities. Therefore, we carried out analysis of news content, the regional historiography, and socio-cultural practices of the border. The article instigates think the border as region porous and selective, which is characterized by an border identity marked by chamges cultural missionaries, gauchos, and riverine.
\end{abstract}

Keywords: Bridge integration. Border Brazil-Argentina. Border cultural. Social representations. Identity border. 


\section{CONSIDERAÇÕES INICIAIS...}

O recorte em estudo, a fronteira São Borja-Brasil/Santo ToméArgentina, está regionalizada no bioma pampa, também conhecido como região socioambiental de campanha. Geograficamente, essas cidades gêmeas localizam-se, respectivamente, nas regiões Sudoeste Rio-Grandense e Departamento de Santo Tomé, Província de Corrientes, Argentina. Essas municipalidades também podem ser consideradas integrantes da chamada região histórica das Missões Jesuítico-Guarani da América do Sul.

A fronteira estudada limita-se via rio Uruguai. Nos últimos séculos, esse rio foi de grande importância socioeconômica, pois serviu como acesso para o translado de índios guaranis da redução jesuítica de Santo Tomé para fundarem a redução de São Francisco de Borja (século $\mathrm{XVI)}$. Assim como, foi via de escoamento da produção de charque e de erva-mate que eram produzidas nessa região.

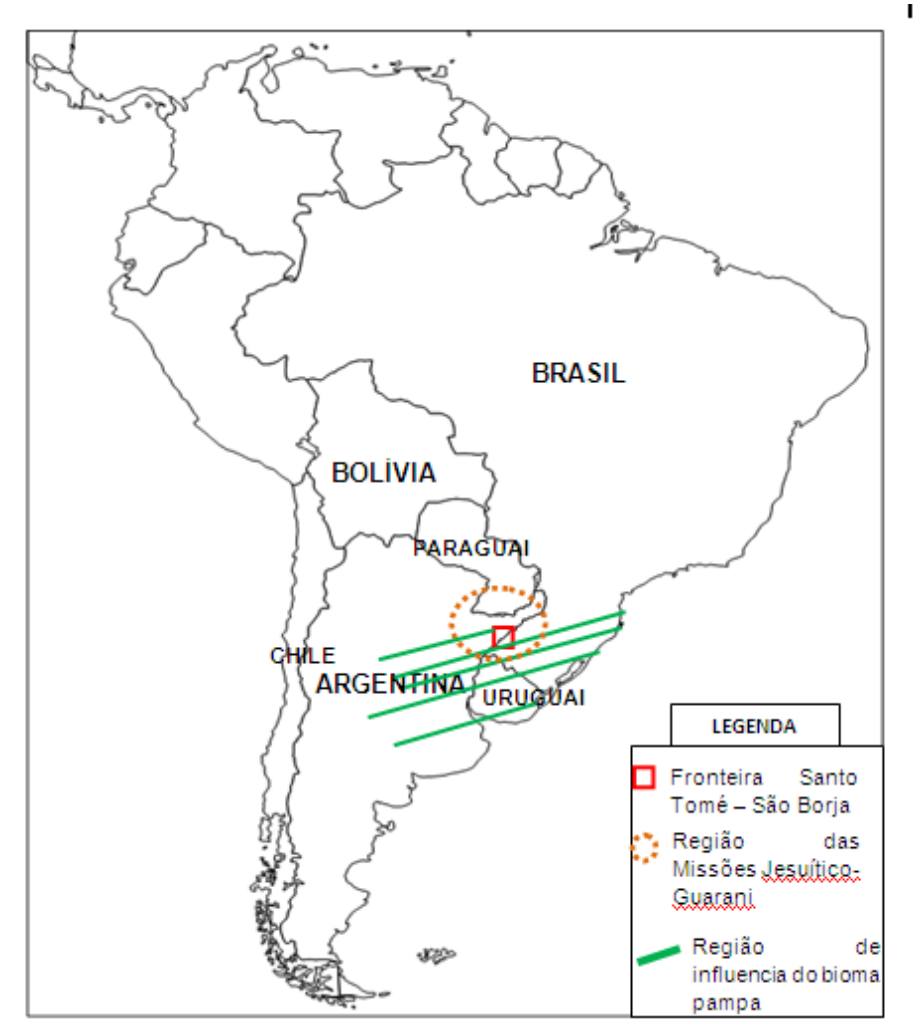


Figura 1: Localização da fronteira São Borja-Brasil/Santo ToméArgentina.

Fonte: Elaborado por Muriel Pinto.

Nas últimas décadas, o rio Uruguai tornou-se uma via estratégica para as relações comerciais do Conesul. Em 1997, foi construída a ponte da Integração na fronteira São Borja-Santo Tomé. Até então, o translado entre as duas municipalidades era via balsa, que ligava o porto no lado brasileiro até o chamado porto do formigueiro no lado argentino.

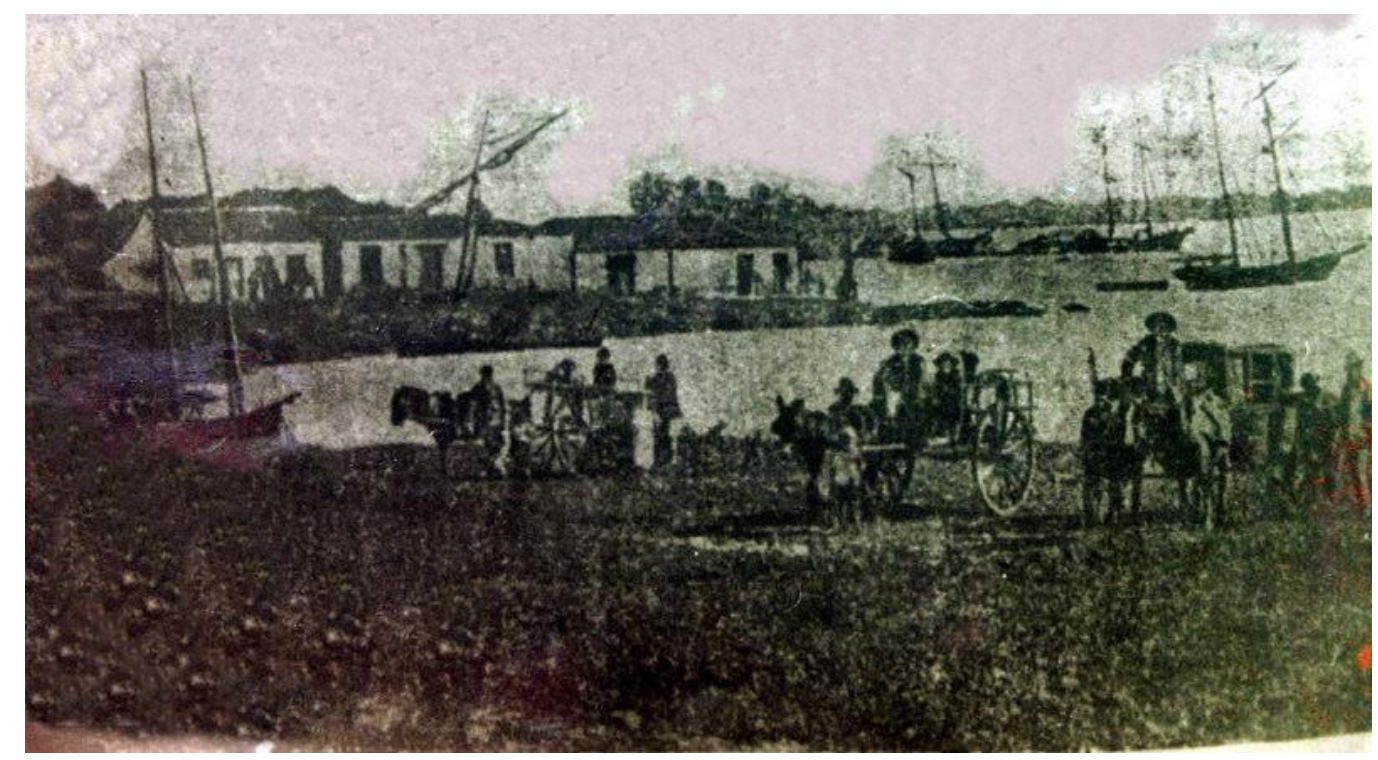

Figura 2: Navegação fluvial em São Borja (1 825).

Fonte: Clóvis Benevenuto.

Conforme o Ministério dos Transportes, foi na década de 1930, no governo Getúlio Vargas, que iniciaram as discussões voltadas para a construção de uma ponte nessa área de fronteira. No entanto, a primeira ponte a ser construída na região fronteira-Oeste do Rio Grande do Sul foi a ponte entre Uruguaiana-Libres. Segundo relatos expostos no jornal a Folha de São Borja, a demora de 60 anos para a construção da obra 
ocorreu em virtude da falta de articulação política e deficiência na elaboração do projeto e do edital de licitação.

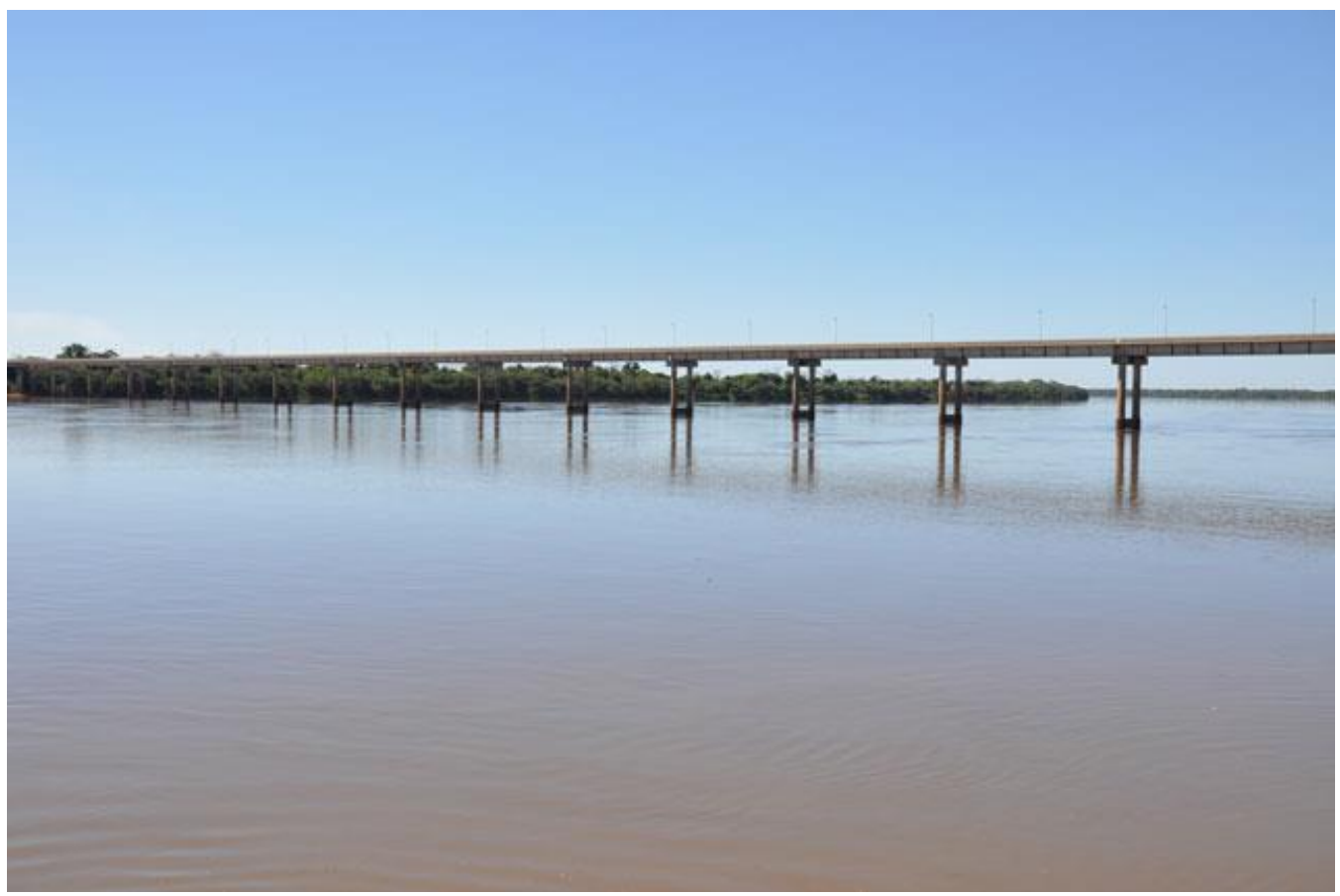

Figura 3: Ponte da Integração São Borja-Santo Tomé.

Fonte: Acisb.

A região fronteiriça São Borja-Santo Tomé esteve envolvida em diversas trajetórias históricas relevantes para o cenário da América do Sul. Tais municipalidades foram reduções Jesutíco-Guaranis (séculos XVI e XVII), seus territórios serviram de entrada para a Guerra do Paraguai, foram locais de nascimento de personalidades políticas e de reacionários, como Getúlio Vargas, João Goulart e Andresito Guacurari, assim como, foram influenciadas pelas relações socioculturais do pampa.

Esses momentos históricos contribuíram para a construção de discursos, símbolos, práticas culturais, tradições e costumes regionais. Tais fatores possibilitaram a produção de diversos bens culturais, que estão espacializados no território fronteiriço por meio de tipologias patrimoniais. As práticas sociais e as manifestações culturais 
fronteiriças representam discursos e símbolos identificados com o período das Reduções Jesuítico-Guaranis.

Esses aglomerados reducionais possuíam um planejamento urbano avançado para a época, que se espelhavam em modelos barrocos. A estrutura urbana das reduções era constituída por cabildo, praça, igreja, cemitério, escolas, oficinas e canteiros. Atualmente, muitos municípios missioneiros adequaram suas áreas centrais ao perímetro urbano das antigas reduções, portanto, as cidades regionais estão organizadas praticamente nas mesmas estruturas reducionais.

Em relação ao processo de instalação das reduções, eram levados em conta diversos fatores geográficos e estratégicos que pudessem contribuir com as políticas comerciais, de defesa territorial e sustentabilidade dos povoados guaranis, como: proximidade de bacias fluviais, busca de pontos altos e de fácil acesso e defesa (GUTIÉRREZ, 1987). Segundo Gutiérrez (1987, p. 16), "na estruturação do sistema de ocupação territorial, as missões se projetam no traçado de notáveis caminhos, na instalação de postos e capelas, canais e zonas de reserva florestal, de pesca, etc".

Conforme Claudete Boff (2011, p.241):

para o sucesso da catequese e a melhor compreensão dos conceitos abstratos que ela impunha, foram usadas várias formas de persuasão para cristianizar. Essas, em sua maioria, estiveram amparados em imagens, pinturas, procissões, festividades, teatros, cantos, enfim, tudo o que pudesse ser exteriorizado, visível e palpável.

Como se observa, as artes foram instrumentos essenciais para a adequação dos guaranis aos aprendizados religiosos. No entanto, cabe destacar que a cultura indígena "manteve-se em muitos de seus padrões culturais, como evidenciam os vestígios arqueológicos: cerâmica artesanal, artefatos de pedra lascada e polida, etc" (KERN, 2011 , p.9).

Muitos aspectos sociais indígenas persistiram: o cacicado, a língua com imensa riqueza verbal, as relações sociais de solidarismo e reciprocidade, as tradições guerreiras, as atividades quotidianas da horticultura, da caça e da pesca. Por outro, a ação consciente dos jesuítas colocou os indígenas frente a frente com as inovações técnicas da sociedade europeia: a escrita e a imprensa, o arado e a metalurgia do ferro, a olaria e a arquitetura barroca, o predomínio da família nuclear e 
a inserção do caciquismo nos órgãos municipais do Cabildo espanhol (KERN, 2011 ).

A partir da análise das manifestações culturais reducionais, percebe-se como procederam as trocas culturais entre guaranis e jesuítas. Conforme Wilde (2011), os indígenas manifestaram atitudes diversas em relação à adequação a materialidades vindas de fora, onde, por exemplo, desprezavam as imagens pintadas e demonstravam "receptividade a cruzes, varas de mando, vestimentas, e aprendizagens técnicas como a escritura, a cartografia, e a implantação de performances como os rituais cristãos, das formulas sacramentais e a música" (WILDE, 2011 , p.15).

Segundo Boff (2011, p. 242), "imagens religiosas foram um importante instrumento à disposição dos jesuítas no trabalho de evangelização dos guarani aldeados, ou seja, a arte foi meio de persuasão, propaganda e pregação catequética no Novo Mundo".

Pela representação imagética das estatuárias, os jesuítas alcançavam seu principal objetivo que era a proliferação da ideia da espiritualidade. Nesse contexto, as imagens barrocas se destacavam por transmitir mensagens evangelizadoras e representavam a interiorização de sua santidade, assim como o recolhimento. Tais características são percebidas a partir do olhar, expressão e a eloquência dos gestos das estatuárias (BOFF, 2011).

$O$ estudo proposto centrou-se em analisar as relações socioculturais da fronteira São Borja-Brasil/Santo Tomé-Argentina, voltando-se para a interpretação das articulações políticas realizadas no período de construção da ponte da Integração, das representações sociais e das identidades socioterritoriais contemporâneas. Para tanto, realizou-se análise de conteúdo jornalístico da historiografia regional e das práticas socioculturais da fronteira, que centrou-se em refletir sobre três momentos históricos, como: o período reducional (século XVI), construção da ponte da Integração, e sobre as representações e práticas sociais contemporâneas.

\section{CONCEITOS SOBRE FRONTEIRAS E IDENTIDADES TERRITORIAIS}

As cidades fronteiriças são os núcleos mais densos das fronteiras, constituindo redes de interação amplas e complexas. Em função das 
especificidades das trocas e relações entre os agentes sociais habitantes dessas áreas, é comum encontrar estudos de fronteira sobre as chamadas cidades-gêmeas (SILVA; OLIVEIRA, 2008).

Para Oliveira e Silva (2008), as cidades-gêmeas são pares de centros urbanos geograficamente próximos, divididos por um limite internacional, que podem ser definidas como núcleos centrais da fronteira. No caso das cidades de faixa de fronteira, são de maior valia as interações com espaços não contíguos do que com o espaço adjacente.

O processo de construção das fronteiras políticas e das ações de integração transfronteriça envolvem diversos atores. Tais agentes podem estar articulados por diversos níveis sociopolíticos, desde atores federais, estaduais, municipais e representantes da população civil (GRIMSON, 2005). Segundo Grimson (2005), esses atores estão constantemente inseridos em lógicas locais de disputas e articulações, onde os agentes fronteiriços possuem interesses, práticas e discursos contrastantes e não homogêneos aos Estados, o que expõem disputas por características e sentidos da fronteira.

Para Grimson (2005), as fronteiras políticas constituem um terreno produtivo para pensar as relações de poder no plano sociocultural, visto que os interesses e identificações dos atores locais encontram diversas articulações e conflitos com os planos e a penetração do Estado nacional.

Sin embargo, recuperar la dimensión de agencia de las propias poblaciones fronterizas -en lugar de universalizar su supuesta "resistencia" al estado nación- puede revelar que, en muchos casos, hay una dialéctica entre "arriba" y "abajo". Las comunidades fronterizas pueden ser agentes de cambios sociopolíticos significativos más allá de su localidad e incluso más allá de su estado (GRIMSON, 2005, p.67).

Portanto, analizar as agências locais possibilita refletir sobre a produção e reprodução da fronteira. Para Grimson (2005), é necessário refletir sobre a maximização dos beneficios econômicos da existência do limite, em contrapartida da construção fronteiriça amparada nas ações coletivas, práticas cotidianas e manifestações culturais.

Segundo Grimsom (2005, p. 133): 
En el Cono Sur, aunque no conozcamos casos tan extremos, recién comienza a asumirse el desafío de pensar como agentes fronterizos a los jesuitas de las reducciones, a los guaraníes, a los bandeirantes, a los fazendeiros riograndenses y a muchos otros sectores sociales que tuvieron un papel relevante - a través de sus propios éxitos y sus fracasos, como la Guerra Guaranítica de mediados del siglo XVIII- en la construcción de las fronteras políticas en el Cono Sur.

A partir de tal citação, percebe-se que o conhecimento histórico e cultural das regiões fronteiriças tornam-se fatores relevantes para pensar como estão constituidas as fronteiras políticas e as relações socioculturais transfronteiriças. O desafio proposto por Grimsom, de pensar os jesuitas, guaranis e fazendeiros riograndenses como agentes fronteiriços, vem ao encontro do proceso de construção e integração da fronteira entre Brasil e Argentina, que é o recorte exposto pelo estudo. Esses atores contribuíram para a estruturação de ações culturais, econômicas e sociais que estavam integradas nas margens do rio Uruguai.

As fronteiras são, nesse sentido, lugares de práticas, trocas e conflitos vitais para o social, o conhecimento do outro, o reforço da identidade e um espaço propício para a difusão cultural com um forte valor simbólico (VELASCO-GRACIET, 2008). Para Grimson (2005), as zonas fronteiriças constituem espaços onde se produzem identidades transnacionais, assim como conflitos entre grupos nacionais. Nesse sentido, as manifestações culturais e identidades regionais servem como artifícios para entender a cultura política da fronteira.

Segundo Grimson (2007), compreender ao outro, suas culturas políticas, suas formas de identificação, torna-se decisivo para avançar na interação e em projetos de integração. Nos últimos anos, percebe-se que os Estados diminuíram sua proteção fronteiriça, no entanto, estão utilizando outras formas de controle e regulamentação. Em outras palavras, estamos assistindo, mais que uma desterritorialização generalizada, mas, sim, a uma substituição de um modelo de territorritorialização por outro (GRIMSON, 2005).

A construção de pontes nas áreas fronteiriças do Conesul destacam-se como principais projetos que reforçam o controle da fronteira. Para Grimson (2007), a construção de novas estradas e pontes 
não busca beneficiar as populações fronteiriças, e sim promover o comércio terrestre entre países atravessando cidades fronteiriças. Com tal atitude, os Estados dificultam a circulação de pequenas mercadorias, chamado de "contrabando formiga" e favorecem o fluxo em grande escala.

Uma consequência perceptível com o controle da circulação é a anulação da história e das tradições locais (Grimson, 2007), visto que a construção de pontes expõe a representação de uma divisão territorial, que acaba ignorando as relações sociais, culturais e históricas entre as cidades fronteiriças. Tais atitudes dificultam as trocas e intercâmbios socioculturais entre as populações locais. Esse processo de controle da circulação é descrito por Grimson (2005) como uma nova divisão, que causa novos rancores e disputas na fronteira.

\section{Questão regional}

Bordieu afirma que não existem critérios capazes de fundamentar as classificações em regiões "naturais" separadas por fronteiras "naturais". Trata-se de representações, que podem estar embasadas em critérios objetivos, como ascendência, território, língua, religião, atividade econômica, ou subjetivos, como o sentimento de pertencimento (BARCELLOS e OLIVEIRA, 1998, p. 226).

Ao iniciar-se esta discusão, torna-se necessário conhecer conceitos de região que são abordados por outras disciplinas compósitas 1 , para melhor se entender a maneira que os povoados se formaram e ocuparam os espaços regionais, portanto, "o primeiro e mais imediato de todos é o tratamento da geografia física e humana, que irá identificar a região com base em critérios de delimitação da paisagem natural e étnica"2, também se pode considerar "los factores geográficos, cuya historia hay que considerar, solo adquiren uma importancia decisiva cuando se les relaciona com otros datos, económicos, sociales, culturales" (BRAUDEL, 1992, p. 115).

1 Compósitas é a união de duas ciências num substantivo e num epíteto: história sociológica, demografia histórica, antropologia histórica; Ver mais em LE GOFF, Jacques. A história nova. São Paulo: Martins Fontes, 1998. p.26.

2 NORONHA, Márcio Pizarro. Região, identificações culturais, in: História: debates e tendências, Passo Fundo: EDIUPF, jun. 1998, v.1, n.1. pág. 25. 
Segundo Reckziegel (1999), há uma tendência entre os historiadores de assimilar e utilizar os conceitos produzidos pelos geógrafos, mas que, entre as muitas vertentes explicativas para o termo região, há um ponto consensual de que região seria a particularização dos lugares, a sua individualização. Portanto, poderíamos aceitar como válida a região "como um espaço de identidade ideológico-cultural e representatividade política, articulado em torno de interesses específicos, geralmente econômicos, por uma fração ou bloco regional de classe que nele reconhece sua base territorial"3.

O fio condutor desta discussão envolve uma comunidade que pertence a uma região hoje denominada de campanha, que já tinha seus espaços particularizados e individualizada pela situação imposta pelos conquistadores, balizada dentro de um contexto de fronteira, criada ainda quando não tínhamos limites políticos definidos, e somente mais tarde esses limites foram definidos pela criação da fronteira do Rio Grande do Sul com a Província de Corrientes.

\footnotetext{
Região, ao invés de ser apenas um referente (no caso específico da delimitação a um tipo de configuração geográfico-espacial), passa a ser um modo de proceder - um tratamento metodológico - que visa estabelecer uma relação específica no âmbito de uma cartografia simbólica, que deverá incluir os níveis do local, do regional, do nacional e do transnacional (NORONHA, 1998, p. 26).
}

No entanto, esta abordagem, onde se discute o regional com enfoque à região de São Borja-RS, instiga refletir estudos locais, regionais, nacionais e internacionais, pois trata-se de uma localidade de fronteira e que configurava uma preocupação constante para o governo brasileiro e gaúcho, por fazer limite com a Argentina e ambos faziam parte da Bacia do Prata. Portanto, o perigo estava sempre eminente nessa região por ser um local de fronteira. Sendo assim, o governo tinha uma grande preocupação em fortalecer essas posições para dificultar uma possível invasão por parte de outros povos e também impedir o contrabando, prática constante nessa região mesmo antes da instalação da redução.

\footnotetext{
3 RECKIZIEGEL, Ana Luiza Gobbi Setti. A diplomacia marginal: vinculações políticas entre o Rio Grande do Sul e Uruguai (1893-1904). Passo Fundo: EDIUPF, 1999. pág. 20.
} 
O gado que habitava essas regiões estava solto. As estâncias começam a ser demarcadas a partir de 1815 e essas demarcações eram feitas pelos limites naturais, pois os cercamentos começam a ocorrer nessa região nos meados de 1890 , com a chegada do arame de farpa, criado pelos ingleses em 1870, iniciando, assim, seu processo de desenvolvimento econômico voltado à criação de gado em propriedades de grandes extensões de terras, ou seja, o início dos latifúndios.

A exemplo do país francês, região proposta por Vidal de La Blache, considerado o fundador da geografia regional clássica, a Campanha era considerada uma região no sentido de envolver uma paisagem relativamente uniforme e um "gênero de vida" específico, representado pela criação de gado em suas grandes propriedades campestres, a herança cultural lusa e espanhola e as práticas tradicionais do gaúcho (HAESBAERT, 1988, p. 16). ${ }^{4}$

Dentro da história define-se região como um espaço, sendo que, para a história regional, o espaço não é só físico, pois é cultural, social, político, econômico e ideológico, portanto, é produzida para a sociedade sob uma base territorial determinada. Este espaço é balizado por identidades comuns, sendo a história encarregada de dar a "cara" para esse espaço. A região está configurada como uma fração estruturada do todo.

A região é identidade, cria tipos sociais regionais, e possui as suas especificidades que são historicamente construídas. Pode-se inserir dentro dessa especificidade da região, o contrabando-prática que perdura até os dias atuais na fronteira. A construção sociocultural de uma região envolve relações de poder, ela é uma representação e uma ideologia, principalmente quando esta primeira é apropriada pelos grupos dominantes e assimilada pelo resto da sociedade. Então, essa representação será ideológica.

A identidade socioterritorial manifesta-se através de condições espaço-temporais. Um fator importante nos seus processos construtivos é sua dimensão histórica do imaginário social, que está estruturada a

\footnotetext{
4 HAESBAERT, Rogério. RS: Latifúndio e identidade regional. Porto Alegre: Mercado
} Aberto, 1988. pág.16. 
partir da referência a um território, tanto no sentido simbólico como no concreto (SOUZA, 2001).

Haesbaert (1999) destaca que, para se entender a identidade social, a mediação do espaço torna-se vital na construção da identidade territorial, pois pode discutir a noção de símbolo.

Uma das bases que pode dar mais consistência e eficácia ao poder simbólico da identidade são os referenciais concretos aos quais ela faz referência para ser construída. Nessa perspectiva, percebe-se que o poder da identidade social é, muitas vezes, mais forte e eficaz do que o poder "objetivo", mais concreto, porque o poder simbólico é mais sutil em suas formas de manifestação e, portanto, mais dificilmente reconhecido (HAESBAERT, 1999).

Apesar da região ter suas articulações com o todo, ela possui características próprias, autônomas, que singularizam desse todo o local, e o local é o conjunto das relações sociais que atuam dentro do regional, que se sustentam por meio da diversidade de lugares, que expõem, ao mesmo tempo, práticas sociais, representações culturais e ideias comunitárias e localistas.

A partir dessa reflexão teórica sobre a questão regional, propõem-se pensar a fronteira São Borja-Brasil/Santo Tomé-Argentina, a partir de uma análise regional, onde buscou-se pensar as questões socioculturais, históricas, e políticas fronteiriças através de uma interpretação territorial que valorizasse a fronteira enquanto região.

\section{ANÁLISE DO CONTEÚDO DO JORNAL FOLHA DE SÃO BORJA}

O tópico seguinte objetivou-se em realizar uma análise de conteúdo das narrativas emitidas no jornal Folha de São Borja, durante o período de construção da ponte da Integração São Borja-Brasil/Santo Tomé-Argentina (1994-1997). Para tanto, procurou-se analisar os processos de articulação política Binacional; Identificar as narrativas de exaltação das relações socioculturais fronteiriças; e analisar os discursos de valorização da história fronteiriça (pertencimento as missões) reproduzidos no jornal.

A análise de conteúdo pode ser descrita como um conjunto de técnicas de análise das comunicações. Para Laurence Bardin (1977), um 
dos principais estudiosos dessa temática, a análise de conteúdo pode ser conceituada como:

\begin{abstract}
Um conjunto de técnicas de análise das comunicações visando obter, por procedimentos, sistemáticos e objetivos de descrição de conteúdos das mensagens, indicadores (quantitativos ou não) que permitam a inferência de conhecimentos relativos ás condições de produção/ recepção destas mensagens (BARDIN, 1977, p. 42).
\end{abstract}

Nesse sentido, cabe comentar que uma das principais funções da análise do conteúdo é a inferência de conhecimentos relativos as condições de produção (ou, eventualmente, de recepção) de mensagens. Portanto, preocupa-se em analisar os "significados", embora possa ser também uma análise dos "significantes" inseridos no processo de construção das narrativas (BARDIN, 1977).

Essa abordagem destaca-se por possuir uma grande quantidade de instrumentos metodológicos que estão adequados conforme os campos de aplicação. Para Bardin (1977, p. 42), a devida abordagem "tem por finalidade efetuar deduções lógicas e justificadas, referentes à origem das mensagens, tomadas em consideração (o emissor e o seu contexto, ou, eventualmente, os efeitos dessas mensagens)". Entre suas principais características destacam-se as interpretações sistêmicas e objetivas.

Segundo Bardin (1977), apelar para esses instrumentos é tornarse desconfiado relativamente aos pressupostos, lutar contra a evidência do saber subjetivo, destruir a intuição em proveito do construído. Essa atitude de vigilância crítica exige o rodeio metodológico e o emprego de técnicas de ruptura. Entre os principais objetivos da análise de conteúdo, salienta-se a ultrapassagem da incerteza e o enriquecimento da leitura (BARDIN, 1977).

A análise do conteúdo organiza-se por meio de três fases: I) a pré-análise, II) exploração do material, III) e o tratamento dos resultados, a inferência e interpretação. A pré-análise destaca-se pela a escolha dos documentos a serem submetidos à análise. A escolha dos documentos deve primar pela regra da exaustividade, que objetiva levantar o numero máximo de mensagens (BARDIN, 1977). 
Para Bardin (1977) a leitura flutuante pode ser descrita como a primeira atividade a ser realizada na pré-analise, esta que depende do manuzeio de documentos e conhecimento do texto. A exploração do material é uma fase longa que requer um tratamento e interpretação das narrativas. Segundo Bardin (1977) o tratamento do material pode ser definido como codificá-lo, neste processo as unidades de registro e contexto tornam-se instrumentos essenciais, pois estão adequadas as analises qualitativas. A partir dos registros são realizados recortes nos textos, que contribuem para a constituição de unidades de base, como exemplos destas cita-se o levantamento de "temas" que podem serem identificados através de frases.

o tema é a unidade de significação que se liberta naturalmente de um texto analisado segundo critérios relativos á teoria que serve de base a leitura. O texto pode ser recortado em ideias constituintes, em enunciados e em preposições portadoras de significações isoláveis (BARDIN, 1977, p.105).

Nessa perspectiva, ressalta-se que as análises baseadas em recortes temáticos, identificam-se com a técnica de enunciação. Segundo Bardin (1977), a técnica da enunciação apoia-se na ideia de comunicação como processo e não como dado, onde assenta-se numa concepção do discurso que o autor denomina como palavra em ato. Sendo assim, "o discurso é uma atualização parcial de processos na sua grande parte inconsciente" (BARDIN, 1977, p. 170).

\section{Metodologia empregada na análise de conteúdo do Jornal Folha de São Borja}

Pré-análise: esta etapa centrou-se em levantar as edições do jornal folha de São Borja que tivessem matérias relacionadas à construção da ponte da Integração. Procurou-se levantar o máximo possível de edições do jornal para se ter um universo maior de interpretação do conteúdo jornalístico. Além dos documentos jornalísticos, foram encontrada edições especiais sobre o processo de construção da ponte. O levantamento inicial dos documentos contribuiu para a estruturação do projeto e dos objetivos propostos para o estudo. 
Exploração do material: a seguinte etapa objetivou-se em analisar os conteúdos expostos nas edições do jornal. Para tanto, optou-se pela utilização da técnica de enunciação, que se preocupa em interpretar o processo de produção das narrativas. Essa técnica procurou analisar os textos por meio de duas etapas: as unidades de registro (os títulos e conteúdos das matérias foram divididos em temas), e unidade de contexto (procurou compreender as unidades de registro, ou seja, são as mensagens emitidas pelos temas).

\section{Análise temática}

Sendo assim, após a leitura do Jornal folha de São Borja, levantouse os seguintes temas:

- Processo de licitação da obra da ponte;

- Opiniões sobre a construção da obra;

- Relação histórica da fronteira São Borja-Santo Tomé;

- Anúncio do consórcio vencedor para a construção (ato de inicio da obra);

- Panorama da construção da obra (símbolos da construção);

- planejamento da prefeitura municipal de São Borja para a nova realidade local;

- Conteúdos públicos e comerciários sobre a ponte;

- Importância da obra para a integração sulamericana;

- Benefícios econômicos e sociais com a ponte;

No decorrer dos recortes realizados, percebeu-se que as discussões centraram-se em dois acontecimentos: no processo de licitação da obra e na construção da ponte. Entre os temas relacionados à licitação, observou-se que, para o lançamento da mesma, houve diversas mobilizações políticas e comunitárias que objetivavam uma maior representatividade perante os governos federal e estadual/provincial dos dois países. Esta mobilização contribuiu para a criação da Comissão Mista Brasileira-Argentina-COMAB, que ficará responsável pelas negociações políticas-administrativas da obra. Ainda foram levantados outros temas sobre a licitação, como: "lançamento oficial do edital da ponte", "anúncio do consórcio vencedor para construção da ponte", e "participação do prefeito de São Borja, Luiz Carlos Heinze, nas decisões sobre a obra (exposição política)". 
Em relação à temática relacionada ao processo de construção da ponte da Integração, foram inventariadas diversas unidades de registro que exaltavam as etapas da obra como atos simbólicos, como pode ser analisado nos títulos seguintes: "ferro e cimento simbolizam mais de meio século de luta coletiva", e "emoção com a colocação da primeira viga no lado brasileiro". Outro recorte que chamou a atenção foi o projeto de mudança do traçado da ponte proposto por Santo Tomé.

Ainda cabe comentar que durante, o processo de construção da ponte, registrou-se diversas opiniões políticas sobre a importância da obra, assim como foram reproduzidas mensagens de valorização da relação histórico-cultural da fronteira São Borja-Santo Tomé. Os benefícios econômicos da obra foram um tema constante nesse cenário. A prefeitura municipal de São Borja, por diversos momentos, apresentou propostas para um melhor planejamento urbano, social e econômica da cidade. A concretização do Mercosul foi, por diversas vezes, discutida como um ponto positivo para a construção da ponte.

\section{Análise contextual}

Como afirma Bardin (1977), os temas ressaltam os "núcleos de sentido" dos textos. Após o levantamento dos temas, torna-se importante analisar as mensagens emitidas sobre os recortes realizados. Nesse sentido, o estudo proposto centrou-se em realizar uma análise contextual que procurou refletir sobre as articulações políticas e institucionais realizadas no processo de construção da obra, assim como analisar as mensagens de exaltação histórica e cultural das relações de fronteira entre São Borja e Santo Tomé. Para tanto, foi dada atenção para a análise dos principais atores e instituições envolvidas no processo de construção da ponte da Integração.

A análise contextual do conteúdo jornalístico da Folha de São Borja centrou-se, num primeiro momento, em identificar quais foram os principais tipos de escrita que predominaram nos documentos analisados. Entre os principais cita-se: opiniões, artigos, agradecimentos, encartes especiais sobre a ponte, matéria jornalística, exposição de projeto municipal, informe, felicitações, entrevistas, entre outros. 
Em relação às vozes que emitiram mensagens nas edições do jornal, pode-se afirmar que as mensagens políticas foram os discursos que predominaram ao longo da interpretação. Os políticos que escreveram mensagens foram: o então Governador do Estado do Rio Grande do Sul, Antônio Britto, Luis Carlos Heinze (Prefeito de São Borja), Odacir Klein (Ministro dos Transportes, do governo FHC), Rolando Romero Ferris (Governador da Província de Corrientes), Beatriz Farizano (Intendente de Santo Tomé), entre outros. Também foram levantadas mensagens institucionais, como da Prefeitura e Câmara de Vereadores de São Borja, Intendência de Santo Tomé e da classe empresarial de São Borja.

Desde a análise inicial das edições do jornal folha de São Borja, percebeu-se que a construção da ponte era um projeto almejado há muitas décadas. Conforme diversas mensagens emitidas no jornal, essa obra já era cogitada desde o primeiro mandato do presidente Getúlio Vargas. A construção da ponte da integração em 1997 foi precedida por diversas negociações e articulações políticas.

a primeira decisão formal, viria apenas em agosto de 1989, pelo ato firmado pelos então presidentes José Sarney e Raul Alfonsin, em Uruguaiana. Pelo acordo de ambos, ficam tomadas duas decisões pioneiras, uma parceria binacional e a concessão de obra pública à iniciativa privada. É criada então a COMAB Comissão Mista Argentina- Brasil, para cuidar do empreendimento (FOLHA DE SÃO BORJA, 19 de Agosto, 1996).

A COMAB era composta pelas principais lideranças políticas e comunitárias das duas municipalidades. Sua função era estratégica nos processos de negociações, tanto na composição do projeto e planejamento financeiro como na supervisão da obra. A figura de Newton Brunelli, então engenheiro da prefeitura municipal de São Borja, e diretor da devida comissão, foi uma personagem importante no processo de articulação e planejamento da ponte da integração. Brunelli foi responsável pelo estudo técnico sobre a viabilidade da obra, juntamente com a contratada Fundação Universidade de CórdobaArgentina.

Num primeiro momento, a obra seria financiada apenas pelos dois países. No entanto, percebeu-se que a mesma só seria viável por meio de parcerias com empresas privadas. Para o financiamento da obra, 
ficou definido que cada país entraria com 8 milhões de dólares, mais uma contrapartida das empresas vencedoras da licitação. As empresas vencedoras teriam 20 anos para concessão. No andamento das negociações diplomáticas, ressalta-se que os governos do Estado do Rio Grande do Sul, da Província de Corrientes, e das municipalidades de São Borja e Santo Tomé tiveram grande importância nas interlocuções de planejamento e execução da obra.

A concretização do edital de licitação teve uma demora de quatro anos, pois houve três processos licitatórios para revelação das empresas vencedoras do processo. Foi no ano de 1995 que definiu-se a empresa Mercovia S.A como vencedora da licitação. Em 1996, foi dado início às obras, que foram concluídas no final de 1997. Como se evidenciou nos documentos, houve diversos contratempos no período de construção da ponte da Integração, como a disputa de municipalidades vizinhas pela obra, e a tentativa de mudança do traçado por parte de Santo Tomé, que almejava que o mesmo cruzasse pela área urbana da cidade.

Em relação à análise das mensagens de exaltação histórica e cultural das relações de fronteira, foram escritos textos que relacionaram a construção da ponte como uma homenagem aos expresidentes nascidos em São Borja, Getúlio Vargas e João Goulart. Tal conteúdo pode ser visto no texto opinativo do Governador do Rio Grande do Sul, Antônio Britto:

não abrimos mão de nosso passado. Temos muito orgulho dele, mas estamos, mais do que nunca, convencidos de que a melhor forma de homenagear Getúlio e Jango, independente de partidos, é construir um futuro de sucesso, com novas oportunidades de educação, saúde e progresso.

Além da exaltação dos ex-presidentes de São Borja, foi mencionada a importância da trajetória histórica e cultural do local, onde o rio Uruguai e o bairro do passo se destacaram como lugares de difusão sociocultural para os diversos momentos históricos da fronteira.

O texto "a travessia do rio nem sempre, serviu a paz, como agora", destacou-se por apresentar mensagens que relacionaram a construção da ponte à zona ribeirinha da cidade.

No decorrer da escrita, mencionou-se o processo de construção da redução de São Francisco de Borja (século XVI) e os confrontos 
bélicos que ocorreram nesta fronteira (como a Guerra do Paraguai e a invasão de Andresito Artigas ${ }^{5}$ ). Também foi dado destaque para as transações pacíficas na fronteira (relações comerciais através do rio Uruguai). Ainda foram narradas as relações de parentescos que existem entre as duas municipalidades, sendo descrita a vontade da população de passar livremente pelo rio Uruguai.

\section{Interpretação do material}

Neste espaço foi dada atenção para uma reflexão sobre a análise do conteúdo do jornal folha de São Borja, através da relação com as discussões teóricas. Como foi relatado anteriormente, o processo de construção da ponte da Integração envolveu diversas articulações e atores fronteiriços. Para Grimson (2005), as intenções de integração das fronteiras envolvem agentes de diversos níveis sociopolíticos.

No caso da fronteira em estudo, percebeu-se que os agentes envolvidos nas negociações da obra foram de vários níveis de governo, como por exemplo, a Comissão Mista Brasil-Argentina, era composta por representantes das municipalidades e da sociedade civil, mas também houve esforços dos municípios, estados e dos governos federais. A Mercovia S.A, empresa vencedora da licitação da obra, pode ser destacada como um ator estratégico do processo, pois foi responsável pela agilização da construção da ponte, o que the deu direito de concessão de 20 anos para cobrança de tarifa aduaneira de passagem de veículos pela fronteira.

Segundo Grimson (2005), esses atores estão inseridos em lógicas de disputas pelas características e sentidos da fronteira, no entanto, não foram notadas nas mensagens jornalísticas, vozes de oposição à construção da ponte. Nesse caso, pode ser descrito que houve uma dialética entre "acima" e "abaixo" nas articulações, nas quais foram percebidas diversas relações de poder dos atores políticos nas diferentes etapas da obra.

Durante análise das matérias jornalísticas, percebeu-se um maior destaque para as vantagens econômicas que a ponte poderia trazer para

\footnotetext{
5 Índio Guarani, considerado um líder revolucionário regional, que lutou contra a decadência das reduções Jesuítico-Guarani.
} 
a fronteira. Grimson (2007) comenta que a construção de pontes e estradas não objetiva beneficiar a população fronteiriça, mas, sim, favorece o comércio de grande escala, dificultando o comércio em menores proporções, chamado de "contrabando formiga".

Portanto, a construção de pontes torna-se uma nova forma de controle e regulamentação da fronteira. O conteúdo analisado está de acordo com as reflexões de Grimson, pois percebeu-se uma preocupação com o aumento do fluxo de caminhões, não havendo fala nenhuma relacionada aos pequenos contrabandistas da fronteira.

Com o policiamento da circulação de pessoas, percebe-se a anulação da história, das manifestações culturais e tradições locais, uma vez que as pontes dificultam as trocas e intercâmbios socioculturais (GRIMSON, 2007). As mensagens analisadas trouxeram a impressão de que a construção da ponte poderia representar uma integração sociocultural fronteiriça.

O texto intitulado "A travessia do rio nem sempre, serviu a paz, como agora", traz, no seu título, um discurso que expõe a devida fronteira como não integrada, marcada por atos e ações de separação, de conflitos. No entanto, no seu contexto, são exaltados diversos momentos históricos que reforçam as relações sociocultuais locais, como foi o caso da ênfase dada ao período das reduções JesuíticoGuaranis. Outro discurso que chamou a atenção foi a relação da construção da obra como uma homenagem aos ex-presidentes Getúlio Vargas e João Goulart. No entanto, cabe ressaltar que tais personalidades políticas não conseguiram, em seus mandatos presidenciais colocar em prática a ponte almejada há décadas.

Grimson (2007) ensina que a melhor compreensão do outro, de suas formas de identificação, sua história, suas manifestações culturais e de suas culturas políticas tornam-se estratégias importantes para a interação e integração. Os conteúdos analisados trazem para a discussão a necessidade de refletir sobre como andam as interações socioculturais da fronteira em questão, pois, conforme afirma Grimson, as manifestações culturais e identidades regionais servem como artifícios para entender a cultura política da fronteira.

\section{AS REPRESENTAÇÕES IDENTITÁRIAS DOS ESPAÇOS SOCIAIS FRONTEIRIÇOS PÓS CONSTRUÇÃO DA PONTE DA INTEGRAÇÃO}


Antes de partir para a discussão das identidades fronteiriças e suas representações sociais, cabe relembrar que o processo de construção da ponte coincidiu com a criação do Mercosul. Após a consolidação do bloco supracitado, entraram em vigorar na Conesul, os ideais de integração, multiculturalismo, circulação de capitais, difusão turístico-cultural, entre outros. Desde a década de 1990, observa-se que diversos projetos internacionais foram criados para melhor planejar os bens culturais e atrativos turísticos das antigas reduções JesuíticoGuaranis. No entanto, deve-se comentar que a fronteira São Borja-Santo Tomé não esteve inserida na grande maioria destas ações de planejamento.

O período pós construção da ponte da integração gerou mudanças nas relações socioculturais das comunidades ribeirinhas da fronteira, pois o traçado da obra foi erguido numa área mais afastada das áreas urbanas das municipalidades. Como foi mencionando anteriormente, as relações comerciais entre brasileiros e argentinos, realizavam-se no porto de São Borja e no porto do formigueiro de Santo Tomé.

A partir do ano de 1994 com a construção da ponte da Integração São Borja-Santo Tomé houve o final do translado de embarcações no antigo porto local, em virtude da mesma ter sido construída em outro espaço. Esse término do translado de pessoas e veículos no antigo porto, ocasionou mudanças culturais e econômicas nessa região ribeirinha, visto que $o$ fluxo era intenso todos os dias da semana. Outro fator que gerou novas mudanças sociais e econômicas nesse local, foi à reestruturação do Cais do Porto, área constituída por bares típicos e uma paisagem privilegiada do rio Uruguai (PINTO, $2010 a$, p. 3).

A partir de tal citação, percebe-se que, com a construção da ponte, deixou de haver um maior contato da população fronteiriça com as manifestações culturais relacionadas ao rio Uruguai, uma vez que, a partir do transporte via balsa, a comunidade era defrontada com paisagens e práticas socioculturais identificadas com a fronteira.

Nesse caso, a ponte representa, ao mesmo tempo, uma integração cultural e uma ruptura de algumas práticas como a ribeirinha. No entanto, a acessibilidade de estar no outro lado possibilita um maior 
contato e conhecimento das manifestações culturais vizinhas, porém, o translado da ponte exige que o habitante fronteiriço possua um veículo, o que dificulta a passagem para o país vizinho, visto que a grande maioria da população local é de baixa renda.

Após a consolidação da obra, houve um aumento significativo da passagem de veículos leves internacionais pela ponte, principalmente de turistas argentinos que rumam ao litoral brasileiro no final de cada ano. Em contrapartida, nota-se uma oscilação na circulação de veículos leves locais pela ponte, que, desde 1998, apresenta ciclos anuais de aumento e queda na passagem de carros.

Portanto, torna-se instigante pensar como as relações comerciais influenciam nas trocas culturais da fronteira, visto que o fluxo de pessoas pela divisa está relacionado às taxas cambiais de seus respectivos países. Sendo assim, "o ciclo de demanda de pessoas de um lado para outro de uma determinada divisa territorial, relaciona-se com a desvalorização cambial de uma moeda nacional ou com maior poder aquisitivo de um determinado país em relação a outro" (PINTO, 2010b, p. 8).

\section{Representações sociais e identidades socioterritoriais fronteiriças}

As representações sociais podem ser descritas como ideias que são refletidas no espaço, portanto, são ações abstratas. Já as paisagens culturais representam elementos materializados no espaço, o que expõe um diálogo das práticas abstratas com os símbolos territoriais, construções que possuem sentidos e significados.

As representações podem ser definidas como formas de conhecimento social, que envolvem uma relação de pertencimento socioespacial reproduzida, principalmente, através de atos de comunicacionais. Uma das principais características das representações sociais são as relações com o outro. Nessa perspectiva, elas não surgem apenas das mediações sociais, elas tornam-se mediações sociais (JOVCHELOVITCH, 2009).

A materialização das representações sociais pode ocorrer por meio de paisagens culturais. Para Maciel (2001), "penetrar nas representações é compreender o espaço tanto através dos processos visíveis, quanto por meio dos aspectos míticos dos lugares, e a 
paisagem pode ser fundamental nesta conexão obrigatória entre pensamento e imagem". Portanto, as paisagens culturais contribuem para a produção de símbolos e elementos culturais que são essenciais para a reflexão em torno das representações sociais. Para tanto, tornase de grande importância analisar as paisagens de forma articulada com as narrativas geradas pelos corpus discursivos.

Refletir sobre as paisagens envolve simbologias orgânicas e ao mesmo tempo manifestações abstratas, que se identificam com determinados valores, saberes e manifestações culturais, em que a busca pelo passado torna-se uma constante. O francês Guy Di Méo, um grande especialista nos estudos dos espaços sociais, define as paisagens como um objeto etnológico. Suas representações se manifestam sobre diversos panoramas, ou sob os pontos de vista do patrimônio, dos lugares de vida e das formas espaciais da atividade econômica.

No que diz respeito às representações e identidades socioculturais fronteiriças, torna-se prudente destacar que as narrativas e símbolos culturais regionais expuseram paisagens e elementos culturais identificados com manifestações culturais relacionados ao pampa, cultura missioneira e ribeirinha6. Tais constatações foram possíveis a partir da análise das imagens e dos conteúdos jornalísticos, discursos públicos ${ }^{7}$, narrativas musicais ${ }^{8}$, materiais de divulgação turística, iconografias, discurso de projetos públicos, como exemplo, ver figura 4. Cabe destacar que houve diversas manifestações de membros da comunidade civil, principalmente nos conteúdos jornalísticos.

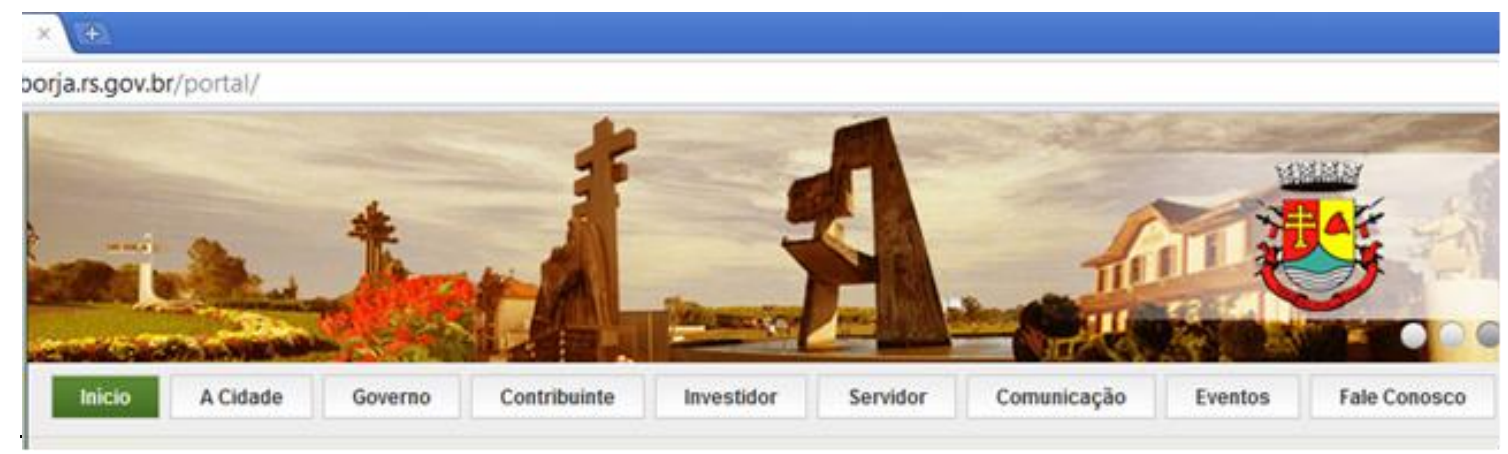

6 Também foram identificados elementos culturais e narrativas sociais que exaltam lideres políticos e militares nacionais.

7 Análise do site da prefeitura de São Borja.

8 Para tanto, foram analisadas as composições musicais do grupo "Os Angueras" de São Borja. 
Figura 4: Layout da Prefeitura municipal de São Borja-RS.

Fonte: Prefeitura de São Borja.

A devida fronteira caracteriza-se por possuir diversos elementos culturais relacionados ao período Jesuítico-Guarani. As áreas urbanas das cidades apresentam diversos marcadores territoriais que estão identificados com as missões, onde percebe-se monumentos e instituições culturais que representam a cultura missioneira. Os municípios simbolizam seus acessos viários com monumentos relacionados às missões, em São Borja (cruz de Lorena, estatuária de São Francisco de Borja e Monumento do Tricentenário da fundação da Redução borjense) e em Santo Tomé (figura mítica do índio Andresito Guazurari Artigas, e monumentos representando o período reducional) (PINTO, 2010b, p. 11).

Além do patrimônio missioneiro, a fronteira apresenta uma grande quantidade de elementos culturais ligados à cultura do pampa ${ }^{9}$, também conhecidas como manifestações gaúchas. Entre essas destacam-se práticas e costumes identificados à lida campeira, como: na dança típica (chamamé), no canto típico (chimarrita), nos artefatos e vestimentas (bombacha, alpargata, boina, chiripá, lenço, cinto, etc), na bebida típica (chimarrão ou mate), na gastronômia (churrasco, pucheiro), manifestações artísticas e populares (festivais musicais, rodeios, grupos de dança e entidades culturais gaúchas) e entre outros (PINTO, 2011). A cultura material e as manifestações artísticas gaúchas estão expostas em museus, Centro de Tradições Gaúchas-CTG e centros culturais. Esses pontos destacam-se como centros de difusão da cultura do pampa.

A musicalidade regional destaca-se como uma importante forma de difusão de representações sociais. Nesta fronteira, anualmente, ocorre uma grande diversidade de festivais musicais ${ }^{10}$, que expõem composições de estilos nativistas, concursos de sambas, e de carnavais.

\footnotetext{
9 Cabe destacar que foram levantados diversos imóveis com arquiteturas ecléticas na região, estas casas em grande escala são de propriedade da classe social dos estancieiros, estes grandes proprietários de terra são reprodutores da cultura do pampa.

10 Festivais: da Barranca, festivais de musicas de Carnaval, Ronda de São Pedro (São Borja), e Festival do Folclore Correntino (Santo Tomé).
} 
Nessas festividades, são exaltadas narrativas e expostos símbolos que emitem discursos de pertencimento à cultura gaúcha, missioneira e ribeirinha (discursos de pertencimento ao rio).

Conforme Di Méo (2005, p. 1), as festas e festividades possuem grandes implicações geográficas:

\begin{abstract}
estes eventos novos ou renovados são caracterizados por cuidados institucionais e uma dimensão artística aumentada. Eles também apontam para o surgimento de suas funções política, ideológica e econômica. Geograficamente, os festivais retratam a identidade e a imagem das cidades, a solidariedade e unidade regional.
\end{abstract}

A partir dessa afirmação de Guy Di Méo, percebe-se que a organização de um evento cultural está marcada pelos sentimentos de pertinência popular e, ao mesmo tempo, por relações de poder. Sendo assim, "além do lugar festivo, são territórios que estão em questão, territórios bem reais, ou somente representados, imaginados e sonhados" (DI MÉO, 2005, p. 237).

Segundo Pinto (2012), no Festival Ronda de São Pedro, observa-se uma manifestação exótica, pois o evento caracteriza-se por ser de músicas gaúchas, com temática junina. A partir dessas peculiaridades, apresenta-se o que Guy Di Méo (2005) defende como geografia das redes através dos festivais, ou seja, a cultura missioneira acaba se integrando com elementos culturais relacionados a outras escalas regionais, como: elementos nordestinos (no caso da Ronda), cultura correntina da Argentina (cultura do chamamé) e cultura rio-grandense.

Já as manifestações ribeirinhas expuseram representações e paisagens identificadas à cultura da pesca, onde o cais do porto se destaca como o principal lugar de difusão cultural dessa área periférica. Uma reflexão necessária é pensar a ponte como símbolo ou marcador territorial que está incluso num espaço social identificado com ideias e práticas ribeirinhas. No entanto, tal obra física contribuiu para a diminuição das embarcações e da navegabilidade no rio Uruguai. 
A região ribeirinha está inserida em espaços com baixo poder aquisitivo. Essas áreas estão afastadas do centro das cidades. Em São Borja, percebe-se que a população ribeirinha está identificada com o bairro do Passo, o que instiga pensar suas práticas e manifestações culturais através de ações comunitárias e práticas sociais que mantêm

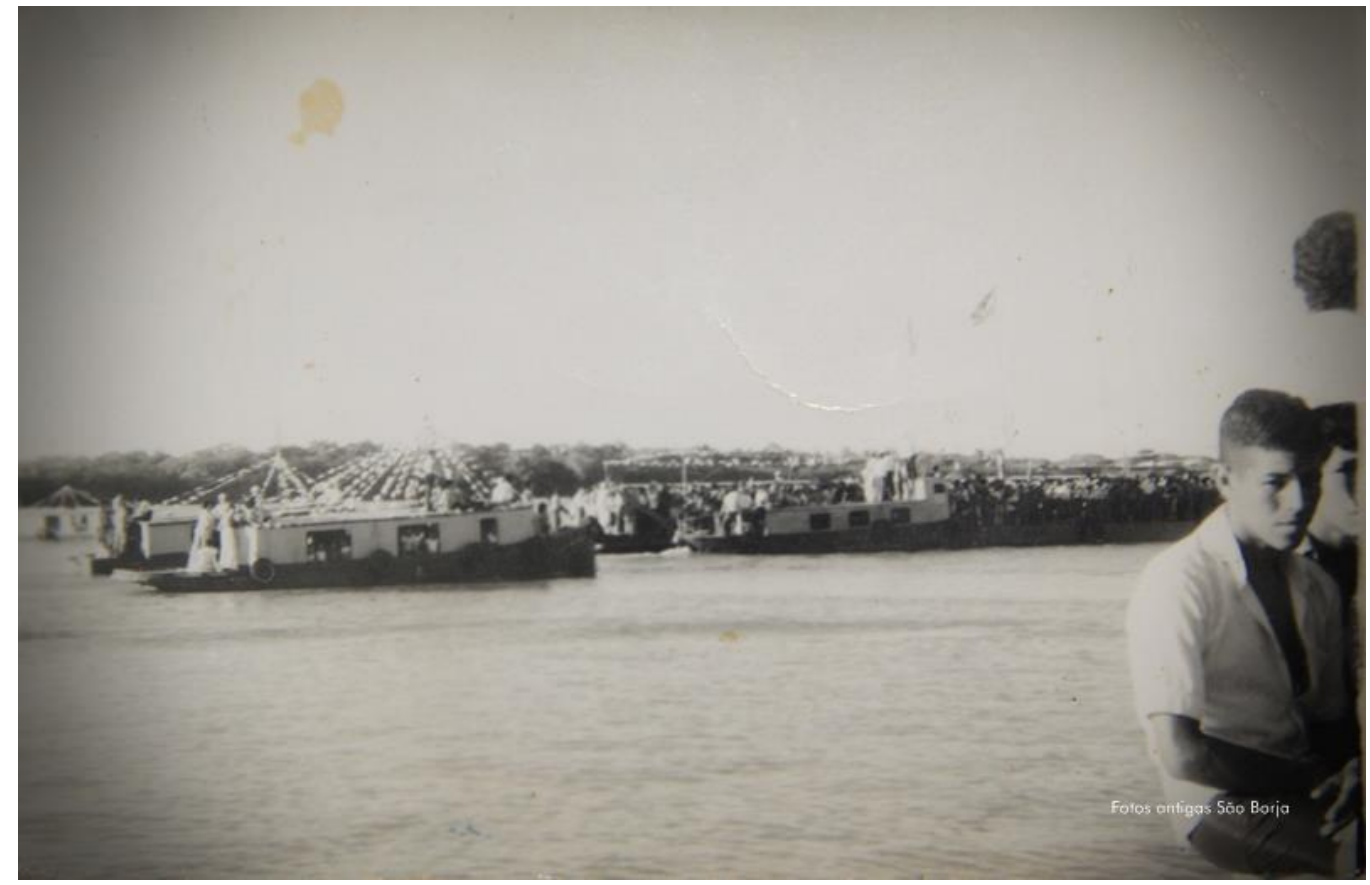

tradições relacionadas desde a fundação da redução de São Francisco de Borja (século XVI).

Figura 5: Procissão de Nossa Senhora dos Navegantes (São Borja).

Fonte: Báu de São Borja.

O cais do porto (bairro do Passo) de São Borja pode ser considerado um dos principais lugares de difusão cultural da fronteira. Nesse local, realizam-se as principais festividades musicais do município, assim como diversas manifestações populares, como o Carnaval e procissão de Nossa Senhora dos Navegantes (ver figura 5).

\section{Identidades socioterritoriais fronteiriças}

A partir da análise das representações e paisagens culturais, foi possível estudar a construção das identidades fronteiriças. Após essa interpretação, observou-se que as identidades missioneira e gaúcha destacam-se como hegemônicas na região. Ainda percebeu-se 
narrativas, práticas e símbolos que representam uma identidade ribeirinha nas margens do rio Uruguai, esta que apresenta características de uma identidade residual como propõem Castells (1999). Com essa linha de raciocínio, instiga-se pensar a identidade fronteiriça como um híbrido entre as representações identitárias identificadas com as manifestações socioculturais missioneiras e pampianas.

A construção identitária é descrita, principalmente na sociologia e na Antropologia, como uma produção social que se ampara nos diferencialismos socioculturais, ou seja, na identificação e comparação relacional com outro (individual)/ outras (sentido coletivo) culturas. Nessas linhas de pensamento, os processos construtivos das identidades são instrumentalizados por meio dos símbolos e discursos sociais.

$\mathrm{Na}$ geografia brasileira, Rogério Haesbaert destaca-se como um dos principais pensadores sobre as identidades territoriais. Haesbaert (1999) trata as identidades territoriais como sendo identidades sociais. Nesse processo, elas se manifestam através de condições espaçotemporais no grupo em que estão inseridas, ou seja, a base material, no caso territorial, serve como sustentação para tais construções (HAESBAERT, 1999).

Seguindo, de certa forma, o pensamento das Ciências Sociais, Haesbaert (1999) defende que a alteridade socioterriorial assume uma função estratégica na criação identitária, pois promove um dialogo de conflito com o outro, em que a percepção das diferenças é fundamental para a afirmação de determinado grupo cultural. A partir da inserção da terminologia socioterritorial, o autor traz para discussão uma reflexão diferenciada para os estudos culturais, pois busca pensar a construção das identidades através da interação com o território.

A construção identitária envolve processos de relações de poder que, na verdade, assim como na constituição dos espaços sociais, estão inseridos num debate político. Atualmente, percebe-se que as influências do mercado vêm utilizando a cultura e as identidades como "recursos", que buscam a diversidade de produtos e manifestações, que objetivam a venda.

A construção das narrativas identitárias dessa área de fronteira apresentaram diálogos com trajetórias históricas e bens patrimoniais 
locais. Essas conexões possibilitaram a invenção de tradições e mitificaram algumas personalidades fronteiriças, como foi o caso de Andresito Guacurari e Getúlio Vargas. Através desses símbolos, sustenta-se o discurso identitário fronteiriço, que é caracterizado pelas trocas culturais entre as identidades missioneira e gaúcha. Nos últimos anos, propôs-se a discussão de pensar a região de fronteira entre a campanha gaúcha e Correntina como um território constituído por uma identidade missioneira-pampiana.

Reckziegel (1999, p. 19) deixa claro que quando nos:

referimos ao inter-relacionamento entre o Rio Grande do Sul e o Uruguai, objetivamos chamar a atenção para o fato que se formou uma região na qual se reconhecem características comuns, isto é, a fronteira entre ambos os territórios foi extrapolada pela existência de uma área compartilhada desde os primórdios da ocupação lusitano-espanhola, moldada por uma história comum.

Este inter-relacionamento citado serve também para a fronteira com a Argentina, em especial aqui, objeto de nosso trabalho, a cidade de São Borja, onde a fronteira não tem poder de influenciar em características culturais adquiridas durante algum período, pois mesmo que "a presença do Estado imponha distinções marcantes entre uma parte e outra, o contato interfronteiriço pode ensejar estilos de vida semelhantes em ambos os lados, o que, algumas vezes, influi na existência de uma identidade regional singular (RECKZIEGEL, 1999, p.19).

No caso estudado, pode-se concluir que a formação das identidades regionais pode sofrer influências ocasionadas pelo interrelacionamento entre países e, no caso específico desta fronteira, ultrapassa os limites determinados pela fronteira no seu caráter político. Para se entender a criação das identidades fronteiriças, torna-se necessário compreender como se desenvolveu a economia da região, quais foram os atores e suas trajetórias históricas.

Quando da formação desta região, tinha-se jesuítas e guaranis, num território pouco conhecido, com culturas e valores econômicos diferentes. Mesmo que as relações de poder exercidas pelos jesuítas na 
cultura guarani fosse de grande influência, ambas as culturas se entrelaçaram formando uma identidade à parte.

Nesta tentativa de analisar a construção da identidade regional, levou-se em conta o início do povoamento reducional por espanhóis e guaranis, mas, deve-se considerar que, após os portugueses definitivamente terem tomado posse da região (século XVII), inicia-se o segundo processo de influência de identidade, com a vinda para esta região de estancieiros portugueses com objetivos de manter a posse do território, que trazem consigo um ator novo, o negro.

Portanto, tem-se índios, espanhóis, portugueses e negros, além de imigrantes, em especial, italianos, franceses e alemães provenientes da Europa, todos com objetivos particulares, com exceção do escravo. A partir da análise da historiografia regional, buscou-se instigar as discussões etnográficas referentes às representações e práticas socioculturais que ainda permanecem na região, desde o período reducional.

O apego a rituais e símbolos religiosos são práticas influenciadas pela colonização espanhola, como exemplo cita-se a procissão de São João Batista, realizada em São Borja (ver figura 6).

Já as celebrações festivas e as manifestações artísticas são práticas originárias dos guaranis. A musicalidade que até hoje torna-se um expoente cultural da fronteira missioneira, teve sua origem no período reducional, onde era comum a utilização de instrumentos clássicos como o violino. 


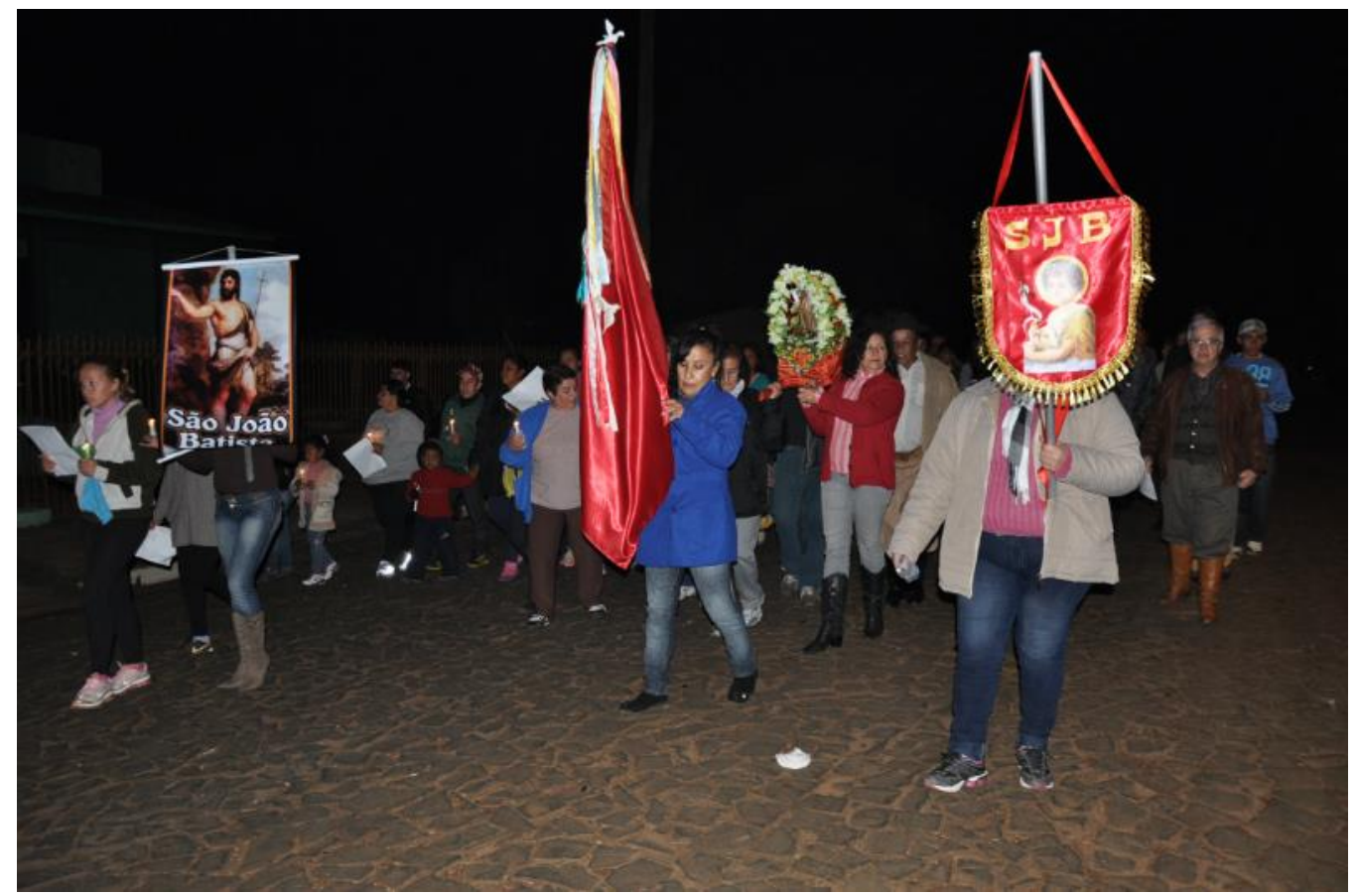

Figura 6: Procissão de São João Batista em São Borja.

Fonte: Prefeitura municipal de São Borja.

Portanto, essa reflexão traz para o cenário a proposta de pensar a construção identitária a partir de uma discussão relacional e comparativa com trajetórias históricas importantes, ou seja, possibilita realizar uma análise identitária em relação a outros espaços-temporais perpassados na região, o que contribuiu para a análise das relações de diferença, semelhanças e as alteridades socioterritoriais da fronteira.

Nas últimas décadas, houve uma transformação da identidade fronteiriça. No Estado do Rio Grande do Sul, surge um movimento de construção da identidade gaúcha, que cria símbolos, narrativas e manifestações culturais identificadas com um tipo social regional, no caso, o gaúcho. A identidade gaúcha sustentou-se no contexto nacional a partir da exaltação da Revolução Farroupilha.

Sendo assim, objetivou-se analisar as trocas culturais existentes entre a cultura missioneira e gaúcha. As representações e simbologias relacionadas ao pampa constantemente estiveram atreladas à história, às tradições e a elementos culturais do período reducional. Esses câmbios culturais estiveram presentes, principalmente, nas festividades musicais, onde tornaram perceptíveis os costumes, exaltações e simbologias da figura do gaucho missioneiro, tipo social regional. 
O gaucho ${ }^{11}$ das Missões destaca-se pela musicalidade do chamamé, tipo musical característico da Província de CorrientesArgentina. Exalta simbologias gaúchas e missioneiras, como a cruz de lorena, narrativas de pertencimento à história reducional, elementos culturais identificados com a lida campeira e exaltação ao rio Uruguai.

Portanto, a criação de identidade fronteiriça está além das fronteiras políticas, pois essa identidade pode servir para aproximar ou para acirrar as diferenças entre regiões.

\begin{abstract}
A fronteira é, por outro lado, uma área estratégica, e as relações que nela se expressam a tornam constantemente móvel, ou seja, as fronteiras são sempre transponíveis por trocas estabelecidas pela sociedade: elas se abrem ou se fecham, dependendo da origem dos interesses que estão presentes. A fronteira ao mesmo tempo proíbe e autoriza a passagem, pois é uma construção histórica resultante de relações de força entre grupos ou classes sociais, típicas de sociedades capitalistas. ${ }^{12}$
\end{abstract}

A formação identitária da fronteira missioneira apresenta particularidades com referência às outras regiões por estar inserida em uma zona de fronteira, onde se tem identidades que muitas vezes são apropriadas, seletivas de objetos, símbolos e significados, sendo útil para refletir as inter-relações entre identidades locais, nacionais e internacionais. Assim como, refletir sobre as relações de poder e os interesses que envolvem a construção e exaltação de determinados discursos e símbolos regionais.

\title{
CONSIDERAÇÕES FINAIS...
}

A fronteira em estudo - as cidades gêmeas de São Borja-Brasil e Santo Tomé-Argentina - está regionalizada num espaço geográfico que

\footnotetext{
1 Vellinho, ao fazer uma comparação entre o gaúcho platino e o rio-grandense, descreve que o platino surgiu da miscigenação dos espanhóis com as índias nativas, enquanto o tipo gaúcho brasileiro se formou através de uma incipiente miscigenação indígena.

12 OLIVEIRA, Naia, BARCELLOS, Tanya M. de. As áreas de fronteira na perspectiva da globalização: reflexões a partir do caso Rio Grande do Sul/Corrientes. Ensaios FEE, Porto Alegre, v.19, n.1, 1998. pág. 225.
} 
foi estratégico para diversas trajetórias históricas do continente americano. Entre esses momentos históricos, destaca-se a fundação das reduções Jesuítico-Guaranis de Santo Tomé (1632) e de São Francisco de Borja (1682), participação na Guerra do Paraguai e foram territórios de nascimentos de importantes lideres políticos e militares, como Getúlio Vargas, João Goulart e Andresito Guacurari. Desde a entrada dos portugueses na região (século XVII), houve uma maior identificação com a lida campeira, pois foi a partir deste período que se iniciaram as áreas de grandes propriedades rurais nas missões. Essa prática da lida campeira contribuiu para a construção de costumes, símbolos e discursos que exaltam o contexto sociocultural do pampa.

Nas últimas décadas, a fronteira São Borja-Santo Tomé tornou-se uma área estratégica para o comércio exterior do Mercosul, em virtude da construção da ponte da Integração em 1997. A execução dessa obra física trouxe mudanças econômicas, sociais e culturais às comunidades ribeirinhas, uma vez que o traçado da ponte foi construído em local mais afastado do cais do porto de São Borja e do porto do formigueiro em Santo Tomé. No entanto, a ponte também possibilitou um maior fluxo de veículos locais para o lado argentino, o que propiciou um maior contato e conhecimento das manifestações culturais vizinhas. Porém, o translado da ponte exige que o habitante fronteiriço possua um veículo, o que dificulta a passagem, visto que a grande maioria da população local é de baixa renda.

Nesse caso, a ponte representa, ao mesmo tempo, uma integração cultural e uma ruptura de algumas práticas, como a ribeirinha. $O$ estudo proposto centrou-se em analisar as relações socioculturais da fronteira, e buscou-se interpretar as articulações políticas, os atores envolvidos e as exaltações histórico-culturais emitidas na construção da ponte (1994-1997). Outro objetivo proposto foi analisar as representações sociais e identidades socioterritoriais fronteiriças. Para tanto, realizouse análise de conteúdo jornalístico da historiografia regional e das práticas socioculturais da fronteira, que centrou-se em refletir sobre três momentos históricos, como: o período reducional (século $\mathrm{XVI}$ ), construção da ponte da integração e sobre as representações e práticas sociais contemporâneas.

Uma das principais contribuições do estudo foi a troca de conhecimentos entre duas áreas irmãs, que são a Geografia e a História. 
Nesses câmbios de pensamentos, procurou-se refletir sobre a fronteira de forma crítica, onde a análise da historiografia, dos espaçostemporais, dos atores e das práticas regionais permitiram integrar as discussões geográficas e históricas com outras áreas do conhecimento, como a antropologia, a sociologia, a psicologia social, e a comunicação social.

Como foi mencionado anteriormente, a fronteira missioneira teve inicio nas suas relações socioculturais e econômicas no período de implementação das reduções jesuíticas (século XVI). A redução de São Francisco de Borja foi fundada por índios oriundos da redução de Santo Tomé. Portanto, a gênese urbana e populacional da fronteira envolveu uma miscigenação étnica e cultural entre os povoados guaranis.

Com a criação do Tratado de Madri (1750), inicia-se um novo paradigma para pensar as relações fronteiriças entre borjenses e santomenhos, visto que até o tratado dos dois territórios eram influenciados por políticas, costumes e práticas socioculturais espanholas. Após, as Missões localizadas na margem oriental do rio Uruguai passaram para domínio da Coroa portuguesa, que realizou ações voltadas para a destruição de elementos e práticas identificadas com o período missioneiro.

Foi com a chegada dos portugueses que a região de São Borja passa a ter um número maior de latifúndios, que estiveram diretamente envolvidos nas atividades campesinas e na pecuária. Uma reflexão necessária é instigar a discussão sobre a relação entre decadência das Missões e a gênese da cultura pampiana a partir da dissiminação das influências da lida campeira pelos grandes proprietários rurais.

Nesse contexto, torna-se prudente analisar o Tratado de Madri como um processo de divisa territorial entre os povoados de São Borja e Santo Tomé, que acabam tendo um maior controle políticoadministrativo após a criação dos Estados nacionais. Propõem-se, a partir desta discussão, pensar a fronteira por meio de uma análise antropológica e política que centrou-se em debater as relações socioculturais e as articulações da comunidade fronteiriças para a concretização de projetos de integração internacional, como foi o caso da ponte da Integração.

A análise do conteúdo do jornal Folha de São Borja objetivou estudar as articulações políticas e institucionais realizadas no processo 
de construção da ponte, assim como analisar as mensagens emitidas de exaltação histórica e cultural das relações de fronteira. Conforme as mensagens do jornal, percebeu-se que essa obra era uma projeto almejado na região há muitas décadas, e já era cogitada desde o primeiro mandato do presidente Getúlio Vargas. Durante a análise das matérias jornalísticas, percebeu-se um maior destaque para as vantagens econômicas que a ponte poderia trazer para a fronteira

No entanto, ao se analisar as mensagens de exaltação histórica e cultural regional, observou-se textos que relacionaram a construção da ponte como uma homenagem aos ex-presidentes nascidos em São Borja, Getúlio Vargas e João Goulart. Nesse sentido, deve-se comentar que tais personalidades políticas não conseguiram em seus mandatos presidenciais colocar em prática a ponte almejada há décadas. A construção da ponte também foi relacionada à zona ribeirinha da cidade, onde foram expostos costumes e práticas presentes no bairro do Passo. A trajetória histórica da fronteira também foi lembrada, como o processo de construção da redução de São Francisco de Borja (século $\mathrm{XVI}$ ) e os confrontos bélicos que ocorreram nesta fronteira (como a Guerra do Paraguai e a invasão de Andresito Artigas 13).

A partir da reflexão teórica amparada nas discussões do argentino Alejandro Grimsom, percebe-se que a construção da ponte proporcionou reflexos cíclicos no que diz respeito a ações de integração e afastamento fronteiriço. Por exemplo, após a construção da obra, houve um aumento do fluxo de veículos, tanto leves nacionais como internacionais. No entanto, quem cruza a fronteira são cidadãos fronteiriços que possuem condições financeiras para ter um veículo. Antes da ponte, o translado era via balsa, o que facilitava a passagem de pessoas com menor poder aquisitivo. Sendo assim, percebe-se uma maior mobilidade de fronteiriços pós ponte, que comercializam produtos, fazem turismo e organizam eventos binacionais.

Por mais que esteja tendo anualmente um aumento do fluxo de veículo leves na ponte, constata-se que a obra trouxe consequências perversas para as comunidades ribeirinhas, pois as mesmas tiveram que se readequar socialmente, culturalmente e economicamente. Até 1997, o translado na fronteira era realizado via barca, entre o cais do porto de

13 Índio guarani considerado um rebelde contra a dominação portuguesa as missões. 
São Borja e Santo Tomé, que localizavam-se nas margens do rio Uruguai. Com a alteração do traçado da ponte houve uma diminuição da difusão cultural ribeirinha, assim como houve a decadência do comércio formiga, que era realizado por pessoas das regiões periféricas das cidades.

As reflexões sobre a ponte permitem interrogar sobre as influências da obra no conhecimento da história, das manifestações culturais e das tradições da frontera. Nos espelhando das preposições de Grimsom, procura-se melhor conhecer e refletir sobre as manifestações culturais e identidades regionais como artifícios para entender a cultura política da fronteira.

Acredita-se que uma das principais contribuições da pesquisa centra-se na melhor compreensão da realidade regional através da articulação entre conhecimentos e reflexões sobre as representações e identidades socioculturais fronteiriças, prospectando entender como estas práticas sociais poderão contribuir para o melhor planejamento de políticas binacionais.

As representações e identidades socioculturais da fronteira expuseram paisagens, narrativas e elementos culturais identificados com manifestações do pampa, cultura missioneira e ribeirinha. A identidade fronteiriça de São Borja e Santo Tomé caracteriza-se pelas trocas culturais entre esses três tipos identitários, que constituem um híbrido, ou mosaico sociocultural que se ampara nas práticas e no discurso pampeano, que cria um tipo social regional conhecido como gaúcho missioneiro. A musicalidade regional destaca-se como a principal representação social da fronteira, que se caracteriza pela musicalidade do chamamé e por discursos de pertencimento ao rio Uruguai, as Missões e a cultura da pesca.

Através do estudo das representações e das identidades, observase que a cultura está sendo utilizada como instrumento de relações de poder através de interesses político-ideológicos, e como produtora de espaços de resistências e autonomias às forças hegemônicas da região. No decorrer das interpretações, observa-se que a fronteira possui duas identidades sociais predominantes, que são as identidades gaúcha e missioneira.

A identidade gaúcha foi descrita como hegemônica na região, em virtude de sua ampla predominância de práticas e de símbolos que 
estão espacializados, tanto nas áreas urbanas como nas áreas de campanhas fronteiriças. Suas manifestações são utilizadas como artifícios políticos, principalmente por partidos ligados aos grandes produtores rurais, que ostentam suas práticas sociais através de símbolos e construções ecléticas localizadas nas áreas centrais das cidades. A identidade gaúcha está, geralmente, relacionada com a exaltação de lideres políticos, como Getúlio Vargas e João Goulart, que eram estancieiros. No caso de São Borja, a monumentalização dessas personalidades constituiu uma identidade sociopolítica trabalhista. Nessa seara, instiga-se pensar a identidade gaúcha a partir de influências portuguesas.

A análise das práticas sociais e dos discursos regionais permitiram pensar a identidade missioneira como representações que se sustentam através de manifestações populares. As representações e elementos culturais missioneiros são importantes para pensar as semelhanças socioculturais regionais, visto que observa-se, na fronteira, diversas manifestações que foram criadas e praticadas no período reducional, como é o caso das práticas artísticas, religiosas e ribeirinhas. Nessa seara, traz-se a possibilidade de pensar a identidade missioneira a partir de influências espanholas.

Para finalizar, propõe-se pensar a fronteira como uma região que possui semelhanças e diferenças socioculturais, seu fluxo de informações é seletivo e poroso, o que permite refletir sobre uma justaposição socioterritorial fronteiriça. As representações e narrativas identitárias regionais expuseram articulações com diversas escalas territoriais, como o local, regional e nacional. No entanto, defende-se o pressuposto de que a história e as transformações espaciais contemporâneas devem ser refletidas através da base territorial, que é o lugar. Essa discussão requer uma análise mais criteriosa sobre as ações abstratas do território, que dão origem aos espaços sociais e as territorialidades, que trazem para a discussão as ações e objetivos de autonomia espacial.

Sendo assim, o estudo proposto centrou-se em disponibilizar informações e reflexões que objetivaram pensar a relação sociedadecultura-território, desapegando das análises meramente econômicas e funcionais da fronteira, mas, sim, buscando e propondo um pensamento 
que leve em conta os territórios de vida da fronteira e suas ações humanas.

\section{REFERÊNCIAS}

A travessia do rio nem sempre serviu para a Guerra. Jornal Folha de São Borja: Edição comemorativa a construção da ponte da Integração. 1994.

BARDIN, Laurence. Analise de conteúdo. Tradução de Luis Antero Reto e Augusto Pinheito. Lisboa: Edições 70, 1977.

BRAUDEL, Fernand. El Mediterráneo: el espacio y la historia. México: Fondo de Cultura Económica, 1992.

BOFF, Claudete. A produção artística da Redução de San Angel. In: COLVERO, Ronaldo; MAURER Rodrigo (Orgs.). Missões em Mosaico. Da interpretação à prática: um conjunto de experiências. Porto Alegre-RS: Editora Faith, 2011.

BRITTO, Antonio. Opinião sobre a construção da Ponte da Integração São Borja-Santo Tomé. Jornal Folha de São Borja, São Borja, 1994.

CASTELLS, Manuel. O poder da identidade. Tradução Klauss Brandini Gerhardt. SãoPaulo: Paz e Terra, 1999.

GRIMSON, Alejandro. Pasiones nacionales : política y cultura en Brasil y Argentina. 1a. ed. Buenos Aires: Edhasa, 2007. 640 p.

Fronteras, estados e identificaciones en el Cono Sur. En libro: Cultura, política y sociedad Perspectivas latinoamericanas. Daniel Mato. CLACSO, Consejo Latinoamericano de Ciencias Sociales, Ciudad Autónoma de Buenos Aires, Argentina. 2005. pp. 127-142.

GUTIERREZ, Ramón. As missões Jesuiticas dos Guaranis. Rio de Janeiro: SPHAN, 1987. 
HAESBERT, Rogério. Identidades territoriais. In: ROSENDAHL, Z. ; CORRÊA, R. L. (Orgs.). Manifestações da cultura no espaço. Rio de Janeiro: EdUERJ, 1999

HAESBAERT, Rogério. RS: Latifúndio e identidade regional. Porto Alegre: Mercado Aberto, 1988.

JOVCHELOVITCH, Sandra. Vivendo a vida com os outros: intersubjetividade, espaço público e representações sociais. In: GUARESCHI, Pedrinho; JOVCHELOVITCH, Sandra. Textos em representações sociais. 11 ed. Petrópolis, RJ: Vozes, 2009.

KERN, Arno. Entre Mitos e a História: As Missões Jesuíticas Platinas. COLVERO, Ronaldo; MAURER Rodrigo (Orgs.). Missões em Mosaico. Da interpretação à prática: um conjunto de experiências. Porto Alegre-RS: Editora Faith, 2011.

MACIEL, C. A. A. M.. Morfologia da paisagem e imaginário geográfico: uma encruzilhada onto-gnoseológica. Geographia, Niterói, Universidade Federal Fluminense, ano 3, n. 6. p. 1-12, 2001.

MÉO, Guy di. Le renouvellement des fêtes et des festivals, ses implications géographiques. In: Annales de Géographie, 2005/3 n 643, p. 227-243.

NORONHA, Márcio Pizarro. Região, identificações culturais. In: História: debates e tendências. Passo Fundo: EDIUPF, jun. 1998, v.1, n.1.

RECKIZIEGEL, Ana Luiza Gobbi Setti. A diplomacia marginal: vinculações políticas entre o Rio Grande do Sul e Uruguai (1893-1904). Passo Fundo: EDIUPF, 1999.

SILVA, Ricardo Marques; OLIVEIRA, Tito Carlos Machado de. O mérito das cidades-gêmeas nos espaços fronteiriços. In: Revista OIDLES - Vol 2, № 5, Universidade de Malága, 2005. 
OLIVEIRA, Naia, BARCELLOS, Tanya M. de. As áreas de fronteira na perspectiva da globalização: reflexões a partir do caso Rio Grande do Sul/Corrientes. Ensaios FEE, Porto Alegre, v.19, n.1, 1998. pág. 225.

PINTO, Muriel. Interpretação do espaço social da Região Histórica das Missões Jesuítico-Guarani: uma dialética com as reflexões do francês Guy Di Méo. Revista Confins (Paris), v. 16, p. 21, 2012.

A construção de identidades hibridas em território geopoliticamente estratégico: o caso da fronteira missioneira São Borja (Brasil)/ Santo Tomé (Argentina): Revista Naveg@merica, Murcia, Espanha, v. 6, p. 1-17, 2011.

A cidade como fenômeno cultural: os impactos territoriais das transformações do patrimônio cultural e da identidade $\mathrm{n}$ cidade histórica de São Borja-RS: Anais da Associação dos Geógrafos Brasileiros, v. XVI, p. 1-10, 2010a.

Integração Econômica-Cultural como Subsídio para o Planejamento Turístico da Área de Fronteira São Borja-Brasil / Santo Tomé-ARGENTINA. Revista Biblio 3w (Barcelona), v. XV, p. 890, 2010b.

SILVA, Ricardo Marques; OLIVEIRA, Tito Carlos Machado de. O mérito das cidades-gêmeas nos espaços fronteiriços. In: Revista OIDLES - Vol 2, № 5, Universidade de Malága, 2008.

VELASCO-GRACIET, Hélène. Les frontières et les géographes. Géoconfluences. 11 mar 2008. Disponível em $<$ http://geoconfluences.enslyon.fr/doc/typespace/frontier/FrontScient. htm\#1 > Acesso em 20 jul 2012.

VELLINHO, Moysés. Capitania d'el-Rei: aspectos da formação riograndense. Porto Alegre: Globo, 1970.

WILDE, Guilhermo. Objetos, Personas y Alteridad en el Espacio Misional. COLVERO, Ronaldo; MAURER Rodrigo (Orgs.). Missões em Mosaico. Da 
A Região de Fronteira São Borja-Brasil/Santo Tomé-Argentina: as representações...

interpretação à prática: um conjunto de experiências. Porto Alegre-RS: Editora Faith, 2011.

Submetido em 03/03/2013.

Aprovado em 20/10/2015.

Sobre os autores

Muriel Pinto

Licenciado em Geografia. Mestre em Desenvolvimento Regional (UNISC). Doutor em Geografia pela UFRGS. Professor da Universidade Federal do Pampa UNIPAMPA/Campus de São Borja-RS.

Endereço: Rua Bompland, 3400. 97670-000 - São Borja, RS, Brasil.

E-mail: murielpinto@unipampa.edu.br

\section{Ronaldo Bernardino Colvero}

Historiador e Doutor em História pela Pontifícia Universidade Católica do Rio Grande do Sul - PUCRS. Professor Adjunto da Universidade Federal do Pampa UNIPAMPA/Campus de São Borja-RS e Professor do Programa de Pós Graduação em Memória Social e Patrimônio Cultural da Universidade Federal de Pelotas - UFPEL. Endereço: Rua Ver. Alberto Benevenuto, 3200. 97670-000 - São Borja, RS, Brasil. E-mail: ronaldocolvero@unipampa.edu.br 